\title{
DIABETES SELF MANAGEMENT EDUCATION AGAINST TYPE 2 DM PATIENTS INDEPENDENCE IN MANAGING DIET
}

\author{
(Diabetes Self Management Education terhadap Kemandirian Pasien DM Tipe 2 \\ dalam Mengelola Diet)
}

\author{
Hariyono, Okaria Nur Sababa \\ STIKES Insan Cendekia Medika Jombang \\ E-mail: hari_monic@yahoo.com
}

\begin{abstract}
ABSTRAK
Pendahuluan. Diabetes melitus telah menjadi penyebab dari 4,6 juta kematian. Selain itu pengeluaran biaya kesehatan untuk Diabetes Mellitus telah mencapai 465 miliar USD. Komplikasi yang dialami pasien diabetes melitus tipe 2 tersebut menyebabkan penderitanya mengalami ketergantungan dalam mengatur pola diet. Ketidakmandirian pasien dalam mengelola diet disebabkan karena kurangnya pengetahuan dan kurangnya motivasi dalam perawatan diri. Penelitian ini bertujuan untuk mengidentifikasi Efektivitas Diabetes Self Management Education terhadap kemandirian pasien DM yipe 2 dalam mengelola diet. Metode. Jenis penelitian ini adalah Pra experimen. Desain penelitian One-group pra-post test design. Teknik sampling yang digunakan adalah Simple Random Sampling dengan 30 sampel. Analisis statistik menggunakan uji Wilcoxon Signed Rank Test dengan nilai signifikansi $\alpha=0,05$. Hasil. Hasil pre test menunjukkan bahwa hampir seluruh responden $(80 \%)$ atau 24 sampel pada kategori partial care. Sedangkan hasil post test menunjukkan bahwa sebagian besar (56,7\%) atau 17 responden ada pada kategori minimal care. Analisis statistik Wilcoxon menunjukkan $\mathrm{p}=0,000$. Diskusi. Kesimpulan pada penelitian ini bahwa ada efek Diabetes Self Management Education terhadap kemandirian pasien DM tipe 2 dalam mengelola diet.
\end{abstract}

Kata kunci: Diabetes Self Management Education, Diet, Kemandirian

\begin{abstract}
Introduction. Diabetes mellitus has been the cause of 4.6 million deaths. In addition, health expenditure for diabetes mellitus has reached 465 billion USD. Complications experienced by patients with type 2 diabetes mellitus that causes the sufferer to experience dependence in regulating dietary patterns. Patients depend in managing the diet due to a lack of knowledge and lack of motivation in self-care. The purpose of this study was to identify the effectiveness of Diabetes Self-Management Education to independence yipe 2 diabetic patients in managing the diet. Method. This research was a Pre-experimental study. Research design was one group pre-post-test design. The sampling technique used simple random sampling with 30 samples. Data was analyze by using Wilcoxon Signed Rank Test with a significance value of a $=0.05$. Result. Pre-test results showed that almost all respondents (80\%) or 24 samples in the category of partial care. The post-test results showed that the majority (56.7\%) or 17 respondents in the category of minimal care. Statistical analysis showed Wilcoxon $p=0.000$. Discussion. The conclusion of this research showed that the effects of Diabetes Self-Management Education on patient autonomy in managing diet in type 2 diabetes patient.
\end{abstract}

Keywords: Diabetes Self-Management Education, Diet, Independence

\section{INTRODUCTION}

Diabetes mellitus type 2 in most countries has grown as a result of social and cultural change rapidly, increasing aging population, increasing urbanization, dietary changes, reduced physical activity and other behaviors that show a pattern of behavior and unhealthy lifestyle. An increasing number of cases of type 2 diabetes mellitus in the world have increased the complications experienced by patients with type 2 diabetes mellitus, diabetic retinopathy, diabetic nephropathy, stroke, coronary artery disease, diabetic foot, and some other complications (Yuanita, 2013). Complications experienced by patients with type 2 diabetes mellitus that causes the sufferer to experience dependence in terms of insulin therapy, regulate diet and take medication dependency. Patients depend in managing the diet due to a lack of knowledge and lack of motivation in self-care. Thus, patients with type 2 diabetes mellitus in dire need of education to help increase knowledge and understanding about the disease and the patient received treatment so as to increase the independence of patients in the control 
of glucose with diet management (Aditama, 2013).

According to WHO data, more than 346 million people worldwide suffer from diabetes mellitus. This figure is expected to double in 2030 if patients with diabetes mellitus did not get the right intervention. $80 \%$ mortality of diabetes mellitus are at a middle-income country down. The WHO predicts that the increase in the prevalence of diabetes mellitus in Indonesia from 8.4 million in 2000 to around 21.3 million in 2030. The latest data in 2012, Indonesia ranks 7th after Mexico, as many as 7.6 million people with Diabetes Mellitus with an age range $20-79$ years.

Diabetes mellitus has been the cause of 4.6 million deaths. In addition, health expenditure for diabetes mellitus has reached 465 billion USD. International Diabetes Federation (IDF) estimates that as many as 183 million people are unaware that they have diabetes mellitus. Obtained samples of 75 people from 32 countries show has not suffered from the disease due to diabetes mellitus using a traditional lifestyle. Conversely, in some countries like Saudi, India and China are still many who suffer from diabetes mellitus. Based on epidemiological studies in Indonesia, the prevalence of Diabetes Mellitus by 1.5 to $2.3 \%$ in the population aged over 15 years, even in areas of urban prevalence of diabetes mellitus of $14.7 \%$ and by $7.2 \%$ in rural areas. The prevalence increased 2-3 times compared with developed countries, so that Diabetes Mellitus is a serious public health problem. In Jakarta, a survey of patients with diabetes mellitus showed that 1 in 8 people suffer from diabetes mellitus. Preliminary study conducted by researchers at the health department to get the data Jombang in patients with Diabetes Mellitus in 2013 as many as 12.254 inhabitants. This figure is expected to increase and if the patient had complications of Diabetes Mellitus not get appropriate treatment.

Meal planning is a major component of the successful management of type 2 diabetes mellitus in a given meal diet. Patient noncompliance in meal planning is one of the obstacles in the treatment of diabetes mellitus (Tera B. Hanifah, 2011). Lack of family support on dietary Diabetes mellitus also a factor in regulating dietary patterns. Eating habits in the family, including the selection of a fast food menu also influence patient non-adherence to the diet. Of the bad habits will cause bad impact on the healing therapy of diabetes mellitus. Impact caused, among others, thus causing the patient rehospitalisasi recurrence, complications of a stroke. But the fact of independence of patients in the diet is very difficult to implement. Data reported to WHO in 2003 showed that only $50 \%$ of patients with diabetes mellitus type 2 in developed countries are able to independently manage his diet (Tera, 2011).

Self-care is good and true in patients with diabetes mellitus including control of risk factors, may reduce morbidity recurrent or rehospitalisasi, complications and deaths caused by the disease. So the control of type 2 diabetes mellitus are more effective when given priority on early prevention through the efforts of self-care management is right or can be called by Diabetes Self-Management Education. Management is included in the Diabetes Self-Management Education among others with diet. Compliance with type 2 diabetes mellitus patients for treatment programs, especially patients who are at home is very important, because the control of blood glucose levels that will either prevent the onset of complications. Diabetes Self Management Education consider will increase the independence of people with type 2 diabetes mellitus in managing diet (Sutandi, 2012). The purpose of this study was to analyze the effects of Diabetes Self Care Management Education to independence in managing diet in diabetes mellitus patients in hospitals Jombang.

\section{METHODS}

This study was pre-experimental with pre-post-test in one group (One-group pre-post test design. The population in this study was all clients of new cases of diabetes mellitus who visited Poly Medicine Hospital Jombang as many as 46 clients in January to March 2014. The sample in this study was in part the patients with diabetes mellitus type 2 new 
cases who visited Poly Medicine Hospital Jombang as many as 30 clients in January to March 2014. Sampling in this study was simple random sampling. Data was analyze by using Wilcoxon Signed Rank Test with a significance value of $\alpha=0.05$.

\section{RESULT}

Table 1. Frequency Distribution Independence of Type 2 DM Patients in Managing Diet in Poly Disease Hospital Jombang

\begin{tabular}{clcc}
\hline No & Criteria & Frequency & $\mathbf{\%}$ \\
\hline 1 & Total care & 0 & 0 \\
2 & Partial care & 24 & 80 \\
3 & Minimal care & 6 & 20 \\
\hline Total & 30 & 100 \\
\hline
\end{tabular}

Table 2. Frequency Distribution Independence of Type 2 DM Patients in Managing Diet on Poly Jombang Disease Hospital after Diabetes Self Management Education

\begin{tabular}{clcc}
\hline No & Criteria & Frequency & $\mathbf{\%}$ \\
\hline 1 & Total care & 0 & 0 \\
2 & Partial care & 13 & 43,3 \\
3 & Minimal care & 17 & 56,7 \\
\hline Total & 30 & 100 \\
\hline
\end{tabular}

Table 3. Effectiveness of Diabetes Self Management Education to Type 2 DM patients Independence in Managing Diet on Poly Medicine Hospital Jombang

\begin{tabular}{llrrrc}
\hline \multirow{2}{*}{ No Criteria } & \multicolumn{2}{c}{$\begin{array}{c}\text { Before } \\
\text { DSME }\end{array}$} & \multicolumn{2}{c}{$\begin{array}{c}\text { After } \\
\text { DSME }\end{array}$} \\
\cline { 3 - 6 } & & $\mathbf{N}$ & $\mathbf{\%}$ & \multicolumn{1}{c}{$\mathbf{N}$} & $\mathbf{\%}$ \\
\hline 1 & Total care & 0 & 0 & 0 & 0 \\
2 & Partial care & 24 & 80 & 13 & 43,3 \\
3 & Minimal care & 6 & 21 & 17 & 56,7 \\
\hline Total & 30 & 100 & 30 & 100 \\
\hline
\end{tabular}

Wilcoxon $\alpha=0,05 p=0,000$

\section{DISCUSSION}

The research results show that the most of the respondents were female (21 patients) to $70 \%$. Gender is effect on self-reliance in managing diet in patients with diabetes mellitus. According to researchers, women are more submissive in managing women pay more attention to the diet because the body shape and tend to be afraid to do invasive. If a woman has a fear of invasive action, then they will tend to do the diet correctly. The shape of the ideal body weight will increase the confidence in women.

The majority of respondents are aged 55-64 years (18 patients) of 60\%. According to researchers, the age effect on self-reliance in managing the diet, this is due to getting older, the greater the degree of depend. Age of persons is showing signs of willingness and ability, or how a person reacts to his inability.

All respondents (30 patients) had not received information about diabetes selfmanagement education and obtain information from several sources. This relates to the independence of Type 2 diabetic patients in managing their diets. The majority of respondents experienced a partial dependence/ partial care (24 patients) to $80 \%$. The relationship of the three table it can be proved that the lack of information about diabetes self-management education will influence the behavior of people to motivate themselves to play an active role in the healing process are included in the self-reliance in managing the diet. Lack of information of diabetes selfmanagement education is not an independent cause the patient to manage his diet

The effects of diabetes self-management education to the patient autonomy in managing Type 2 diabetes diet is shown by the results of the Wilcoxon statistical test with a significance value of $p=0.000$. In the table it is known that before the extension, most of the patients in the category of partial independence of care (24 patients) to $80 \%$. After being granted intervention in the form of education about diabetes self-management education in the form of dietary guidelines, the data produced by most of the respondents were in the category of minimal care (17 patients) $56.7 \%$. The change is the result of interventions such as the provision of counseling is performing well according to the unit of educational events. 
The results of the study the effectiveness of Diabetes Self-Management Education against the independence of Type 2 diabetic patients in managing the diet, after a given intervention mostly in the category of minimal care (17 patients) and $56.7 \%$ before granted intervention results mostly in the category of partial care (24 patients) to $80 \%$. This shows the effects of Diabetes Self-Management Education to the independence of Type 2 diabetic patients in managing diet in Poly Disease Hospital Jombang.

\section{CONCLUSION}

Diabetes Self Management Education can increase the independence of Type 2 diabetic patients in managing diet.

\section{RECOMMENDATIONS}

Patients with diabetes mellitus better to always look for the information to be used as a source of discourse and motivation to improve patient participation in the healing process. The results of this study are expected to provide the basis of interventions to improve the quality of service as well as the outputs satisfy both the community and hospital.

\section{REFERENCES}

Aditama, Lisa dkk, 2013. Efektivitas Edukasi Terapi Insulin terhadap Pengetahuan dan Perbaikan Glikemik Pasien Diabetes Melitus.Tesis.

Sutandi, Aan, 2012. Self Management Education (DSME) Sebagai Metode Alternatif dalam Perawatan Mandiri Pasien Diabetes Melitus di dalam Keluarga. Jakarta

Tera, Banu H, 2011. Determinan Ketidakpatuhan Diet Penderita Diabetes Melitus Tipe 2.Tesis.

Yuanita, Alvinda, 2013. Pengaruh Diabetes Self Education Terhadap Resiko Terjadinya Ulkus Diabetik Pada Pasien Rawat Jalan Dengan Diabetes Melitus Tipe 2 di RSUD dr. Soebandi Jember. Skripsi. 